\section{OPEN JOURNAL SYSTEMS}

ISSN:2237-2202

\author{
Available on line at Directory of Open Access Journals \\ Journal of Hyperspectral Remote Sensing v.9, n.3 (2019) 138-145 \\ www.periodicos.ufpe.br/revistas/jhrs
}

\section{Journal of Hyperspectral Remote Sensing}

\title{
Aridy index over time in five ecosystems on semiarid
}

\author{
Otacílio A. Santana ${ }^{*}$, José I. Encinas ${ }^{* *}$, Bárbara A. de Sousa ${ }^{*}$, Sandra R. S. do Monte ${ }^{*}$, Valéria S. de O. Costa \\ *Programa de Pós-Graduação em Rede Nacional para Ensino das Ciências Ambientais (ProfCiAmb), Universidade Federal de \\ Pernambuco (UFPE), E-mail: otacilio.santana @ufpe.br (corresponding author). \\ **Faculdade de Tecnologia (FT), Universidade de Brasília (UnB).
}

Received 6 September 2019, accepted 30 October 2019

\begin{abstract}
The local climate change was registered over time (1992-2018) on different land use ecosystems, in Brazilian Semiarid area. The aimed of this work was to analyze aridity index in five ecosystems (Wild Caatinga, Caatinga on management, Cactaceae field, Eucalyptus reforestation, and Fabaceae crop), and to compare this index with environment variables. Meteorological towers and measures with porometer and psychrometers were carried out to collect the data. The main result was that the studied areas are hotter and drier. The Fabaceae crop and Eucalyptus reforestation studied ecosystems already are on Arid classification according with registered aridity index. Wild Caatinga and Cactaceae field ecosystems are on Semiarid classification, and over time Caatinga on management ecosystem pass from Semiarid to Arid classification. The five ecosystems together are classified on Arid climate. The VPD and $\Psi_{\text {soil }}$ were the variables more directly proportional with Aridity index to analyzed ecosystems.

Keywords: local climate change; water deficit; droughts; desertification.
\end{abstract}

\section{Introduction}

The land use changes over time results in a local climate changes. The main response caused by microclimate changes is to accelerate environmental process and trends, like as desertification (Zarch et al., 2015). The effects of microclimate changes could be already register in some Brazilian biomes: the tropical rain forest as Amazon Forest (e.g. increase of fire frequency, Schwartz et al., 2015) and Atlantic Forest (e.g. reduction of water security, Salazar et al., 2015); or savanna/tropical seasonal forest as Cerrado (e.g. extinction of endemic species, Thomas et al., 2004), and Caatinga (Vico et al., 2015). The Caatinga native plant extraction to productive chain (e.g. firewood) resulted in a deficit on local water balance (difference between precipitation and evapotranspiration) (Marengo and Bernasconi, 2015). On large scale, time or space, this changes could be irreversible to climate how described by literature (Arora, 2002; Zarch et al., 2015).

The Climate Classification shows global or small scale (e.g. 1:500 000) and does not represent large scales (e.g. 1:10) where land use changes occurs. For example, the Köppen-Gleiger climate classification was performed on 1:275000 000 scale (Rubel and Kottek, 2010). It is very important to elaborate maps according to the data registered in wild and anthropic ecosystems to know the relationship between small land use changes with environment variables. Therefore, the generalization of climate classification generates an error on management strategies, extractive projects and in sustainability plans (Santana et al., 2010). The Caatinga is classified actually on BSh ( $\mathrm{B}=$ arid, $\mathrm{S}=$ steppe, $\mathrm{h}=$ hot arid; Köppen-Gleiger classification), but the trend is that on 2095, modeled by this classification, this area would be on BWh $(\mathrm{B}=$ arid, $\mathrm{W}=$ desert, $\mathrm{h}=$ hot arid) (Rubel and Kottek, 2010; Marengo and Bernasconi, 2015).

Droughts or Aridity trends? (Marengo and Bernasconi, 2015). It is not easy technically the definition limit of both classification, but a fundamental distinction exists between aridity and droughts, which aridity is a long-term climatic phenomenon, and droughts is a temporary phenomenon (water deficit) (Maliva and Missimer, 2012). What does sustain aridity trends in a local? The literature affirm that on short period the land use and deforestation are the main factor to the aridity (Arora, 2002; Rubel and Kottek, 2010; Marengo and Bernasconi, 2015; Salazar et al., 2015; Schwartz et al., 2015; Zarch et al., 2015; Santana; Encinas, 2016; Santana, 2016, 2017; Lima et al., 2019). The others 
factors are described but on large period as high pressure, continental winds, rain shadow effect, and cold ocean currents according to Maliva and Missimer (2012). Another concept is necessary here: the desertification. Desertification is define as land degradation (the reduction or loss of the biological productivity of land) in arid, semiarid, and dry subhumid areas resulted from various factors including climatic variations and human activities. This process is the turn point on Drought-Aridity classification (Mainguet, 1994).

The index used to represents this changes is the Aridity index over time. This index is a numerical dryness degree at a given location. It would be based exclusively on precipitation per year (e.g. from 0 to $250 \mathrm{~mm}=$ Arid; from 250 to $500 \mathrm{~m}=$ Semiarid). Intergovernmental Panel on Climate Change (IPCC) uses this criterion. The most widely index used would be calculated by ratio between annual precipitation and annual evapotranspiration (UNESCO, 1979), or by water and energy balance: i) Martonne index requires annual mean temperature variable in its equation; ii) Thornthwaite index requires water deficiency and water need by months variables in its equation (Maliva and Missimer, 2012). The aimed of this work was to analyze aridity index over time in five ecosystems on Semiarid and to compare this index with environment variables.

\section{Materials and methods}

The study was carried out on Semiarid areas in five ecosystems (Figure 1): a) Wild Caatinga $\left(9^{\circ} 00^{\prime} 02^{\prime \prime} \mathrm{S}\right.$ and $\left.39^{\circ} 08^{\prime} 30^{\prime \prime} \mathrm{W}\right)$, with 1,819 tree and shrub individuals per hectare, all individuals with circumference to base height $(20 \mathrm{~cm})$ greater than 9 $\mathrm{cm}$ and total height greater than $100 \mathrm{~cm}$ (Rodal et al., 1992); b) Caatinga on management (5'30'05' $\mathrm{S}$ and $39^{\circ} 03^{\prime} 50^{\prime}$ 'W), with 1,164 tree and shrub individuals per hectare, goat presences and with $10 \%$ of tree harvested to each fifteen years; c) Cactaceae field $\left(6^{\circ} 43^{\prime} 51^{\prime \prime} \mathrm{S}\right.$ and $\left.37^{\circ} 04^{\prime} 35^{\prime \prime} \mathrm{W}\right)$, with Opuntia ficus indica (L) Miller presences, one individual per meter square (cropped area on 1990); d) Fabaceae crop (9 $30^{\prime} 44^{\prime \prime} \mathrm{S}$ and $\left.40^{\circ} 42^{\prime} 00^{\prime} \mathrm{W}\right)$, with Phaseolus lunatus L., with $0.8 \mathrm{~m}$ of row spacing and eight seeds per meter (one crop per year, cropped area started on 1990); and e) Eucalyptus reforestation (12 $10^{\prime} 53^{\prime \prime} \mathrm{S}$ and $43^{\circ} 21^{\prime} 24^{\prime \prime}$ '), Eucalyptus urophylla S. T. Blake (Myrtaceae), with three per two meter spacing and twenty and four years old (on 2018). All areas occur on Yellow Oxisol 1 (LAx-1), with depth greater than 6 m (INSA, 2019).

We determine one hectare as a sample area on each environment, subdivided in twenty plots (0.05 ha each). Towers were constructed above canopy in central area of each studied environment, to support the data set equipment. The temperature and rainfall were daily measured to each $16 \mathrm{~s}$ by weather station (Orion 420 PLC, Columbia, Hillsboro, US) with sensors linked in all subplots. The real evapotranspiration (ET) (mm) was estimated by $\mathrm{CO}_{2} / \mathrm{H}_{2} \mathrm{O}$ Analyzer (LI-6262, LiCOr Inc., Lincoln, NB, US). The gas was collected by rubber hose (BEV-Aline $4 \mathrm{~mm}$ of diameter) with two aerosol filters (ACRO 50 PTFE $1 \mu \mathrm{m}$ pore-size, Gelman, Ann Arbor, MI, USA) at a flow rate of $15 \mathrm{~L} \mathrm{~min}^{-1}$ (pump unit: Capex V2X, Charles Austin, Survey, UK), in each subplot (see Santana et al., 2010). The data were stocked in data logger (CR-21X, Campbell Scientific, Logan, US). Vapour Pressure Deficit (VPD) was calculated according to Santana, Cuniat and Imaña-Encinas (2010). The evaporation and plant transpiration were monthly estimated by pan evaporation method and with porometer (LI-1600 Steady State Porometer LiCOr Inc., Lincoln, NB, US), respectively. The water potential of soil $\left(\Psi_{\text {soil }}\right)$ was registered in each sub plot (central position) by soil psychrometers (PST-55, Wescor, Logan, US) at $10,20,30,60$ and $100 \mathrm{~cm}$ depth. This data were measured every $30 \mathrm{~min}$ and recorded with a datalogger (CR-7, Campbell Scientific, Logan, UT).

The UNESCO aridity index $(\mathrm{AI}=$ ratio between annual precipitation and annual evapotranspiration) was used in our work, that is classified in four aridity class: a) Hyperarid AI < 0.03 ; b) Arid $0.03<$ AI $<0.20$; c) Semi-arid $0.20<$ AI < 0.50; and d) Dry subhumid $0.50<$ AI $<0.65$. One-way ANOVA with Bonferroni method was carried out to calculate p-value between the ecosystems (ecosystems effect: $\mathrm{H}_{0}=$ The data of environment variables are significantly equals between the ecosystems). The paired t-test was calculated between the data of first and last studied year. Regression analysis was performed between aridity index (y) and environment variables (x). Linear function was chosen to data adjust because the objective was to observe linear trends on studied period. All analysis were preceded by Shapiro-Wilk normality test, and performed at $95 \%$ confidence (Zar, 2010). 


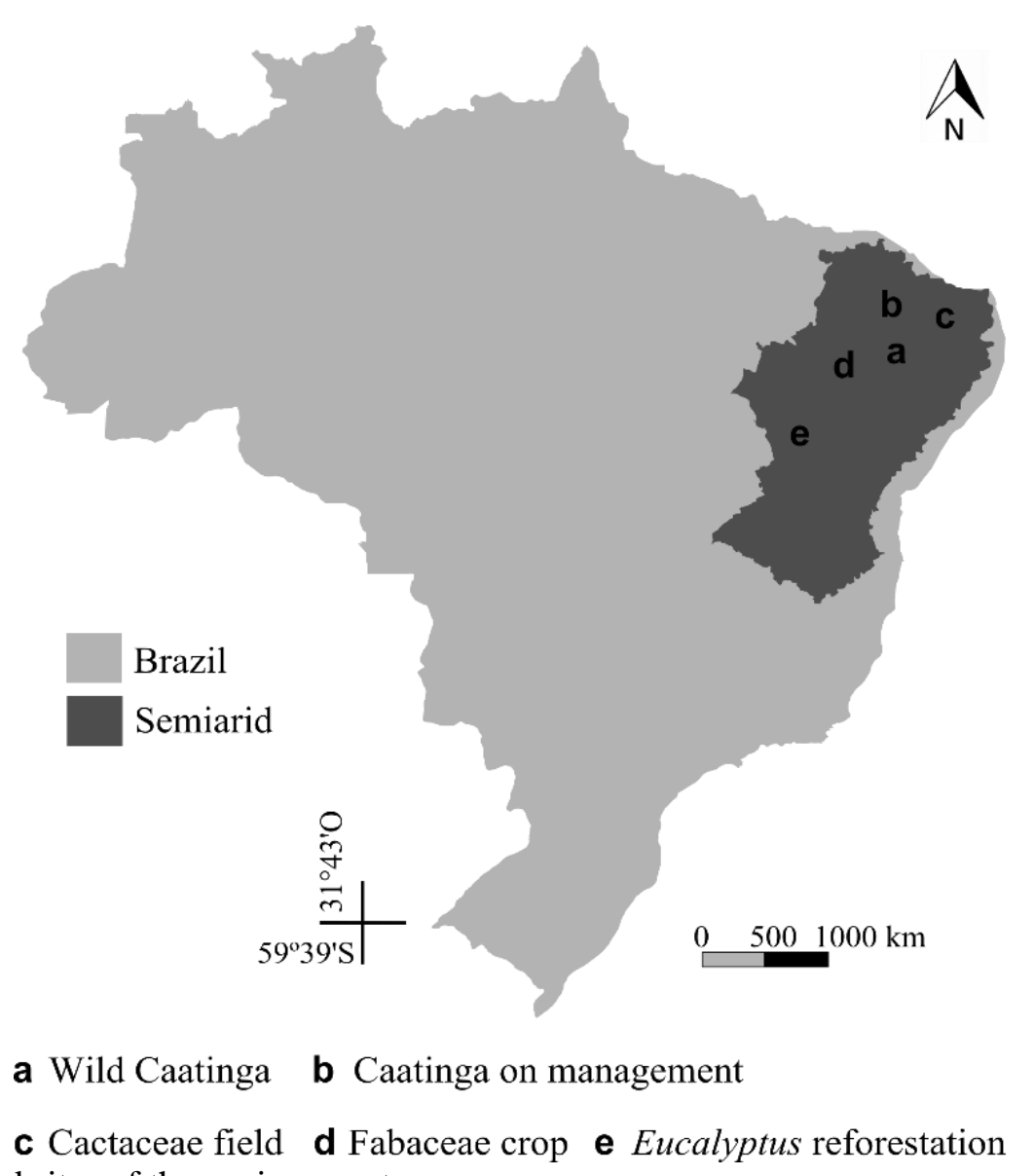

Figure 1 - Study area and sites of the environments.

\section{Results and discussion}

The studied ecosystems was hotter and drier over time on analyzed period and on experimental model (Figure 2). All data in each sample group had normal distribution $(\mathrm{p}<0.001)$. The temperature and rainfall data was not significantly different between the ecosystems ( $p>0.050)$, otherwise the ET, VPD and $\Psi_{\text {soil }}$ was different ( $p<0.001$ : ecosystems effect). In all ecosystems the temperature increased $(\mathrm{p}<$ $0.015)$ and rainfall reduced ( $<<0.001)$, from 2000 to 2018. Moreover, on the same time, this caused an increase in evapotranspiration (ET, $\mathrm{p}<0.001$ ), reduction on vapour deficit pressure (VPD) and water potential of soil $\left(\Psi_{\text {soil }}\right)(\mathrm{p}<0.001)$. Temperature and rainfall values were determined more by geography position than other factor, ET, VPD and $\Psi_{\text {soil }}$ responded the land use. The sequences descendent values were for ET: Eucalyptus reforestation, Fabaceae crop, Caatinga on management, Wild Caatinga, and Cactaceae field; for VPD: Wild Caatinga, Caatinga on management, Eucalyptus reforestation, Fabaceae crop, and Cactaceae field; and for $\Psi_{\text {soil }}$ : Wild Caatinga, Caatinga on management, Cactaceae field, Eucalyptus reforestation, and Fabaceae crop.

The aridity index had its results on Semiarid and arid references (Figure 3; Arid $0.03<\mathrm{AI}<0.20$; Semi-arid $0.20<\mathrm{AI}<0.50$ ). The Wild Caatinga remained on Semiarid classification over time $\left(\mathrm{AI}_{\text {mean }}\right.$ $=0.233)$. The Caatinga on management changes classification from Semiarid to Arid over time (on 2005), but in mean on studied period its AI value was on Semiarid classification $\left(\mathrm{AI}_{\text {mean }}=0.207\right)$. In 2005 (Figure 2), the rainfall is below $400 \mathrm{~mm}$ per year and evapotranspiration is above $2,500 \mathrm{~mm}$ per year. The Cactaceae field had higher $\mathrm{AI}$ value on mean $\left(\mathrm{AI}_{\text {mean }}\right.$ $=0.256$ ) and Fabaceae crop and Eucalyptus reforestation ecosystems with lowers, $\mathrm{AI}_{\text {mean }}=0.152$ and $\mathrm{AI}_{\text {mean }}=0.157$, respectively. The aridity index had significant relation $\left(\mathrm{R}^{2}>0.70\right.$ and $\left.\mathrm{p}<0.001\right)$ with all environment variable, directly proportional with temperature, rainfall, VPD and $\Psi_{\text {soil }}$, and inversely proportional with ET (Figure 3 ). 


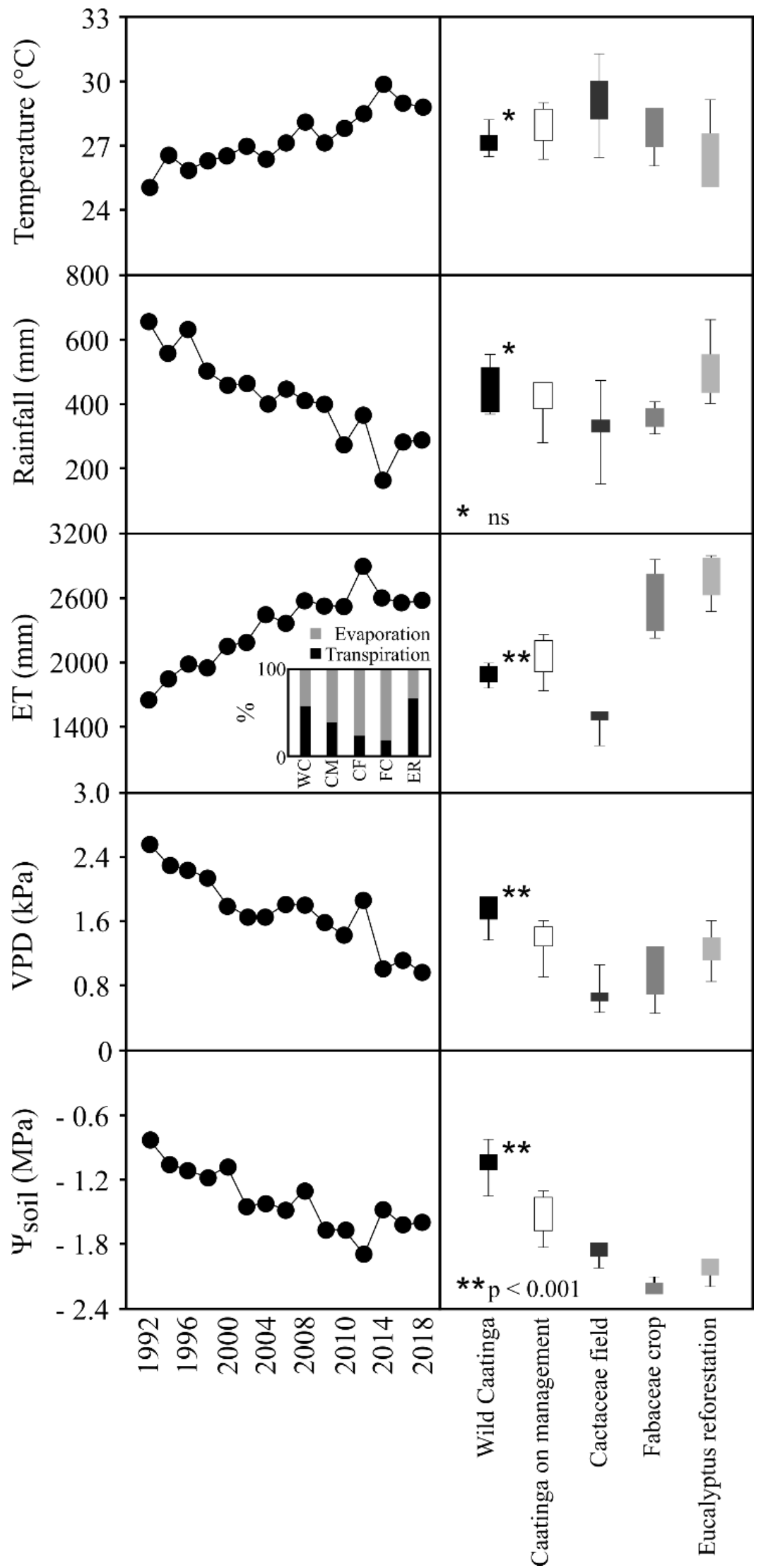

Figure 2 - Environment variables: Temperature, Rainfall, Evapotranspiration (ET), Vapour Pressure Deficit (VPD) and the water potential of soil $\left(\Psi_{\text {soil }}\right)$ over time and its statistical variation on each ecosystems in a Brazilian Semiarid region. 

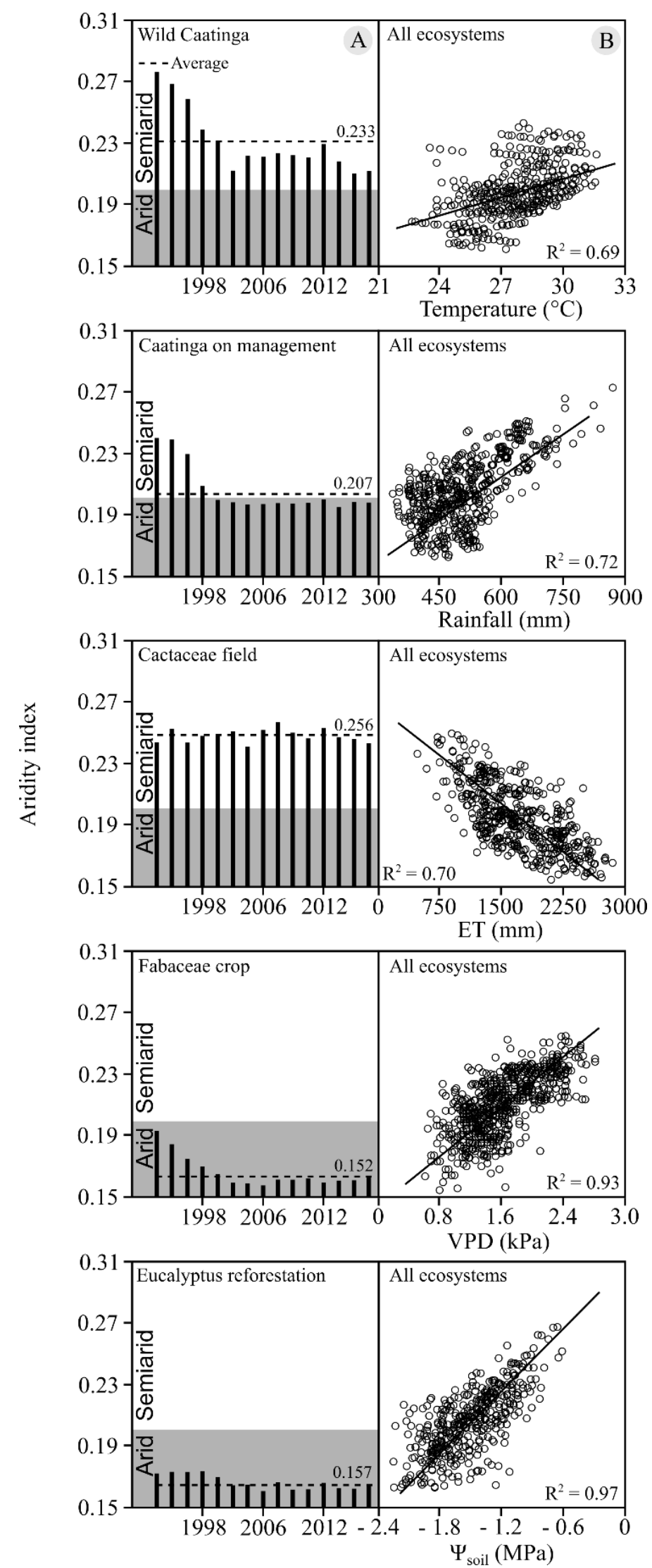

Figure 3 - Environment variables: Temperature, Rainfall, Evapotranspiration (ET), Vapour Pressure Deficit (VPD) and the water potential of soil $\left(\Psi_{\text {soil }}\right)$ over time and its statistical variation on each ecosystems in a Brazilian Semiarid region. 
The data of this work occurred on data range of literature for similar method and climate classification areas (Table 1). Over time others meteorological stations registered hotter and drier microclimates on Semiarid areas (Marengo and Bernasconi, 2015; EMBRAPA SEMIÁRIDO, 2019; INSA, 2019). Why are this occurring? This could be a result of deforestation process, which influences the water cycle. In areas with native vegetation, the water cycle is a climax (Mainguet, 1994; Zarch et al., 2015). The vegetation get water of groundwater by hydraulic lift, and the plants release it to atmosphere by photosynthesis process. Minus tree and shrubs and minus depth roots $(>1.5 \mathrm{~m})$ result in reduction of hydraulic lift, sap flow and free water to system (from groundwater to atmosphere) (Scholz et al., 2010). Moreover, this reduction of leaf area (tree deforestation) cause a reduction of radiation absorption (by photosynthesis process) resulting in increase of the temperature values (Yang et al., 2013). In ET data, other factor is a contribution of evaporation and plant transpiration to system. Eucalyptus reforestation have high plant transpiration than soil evaporation, otherwise, Fabaceae crop have high soil evaporation (soil discovered) than plant transpiration. Caatinga on management in intermediary position with higher ET than Wild Caatinga due the soil discovered (minus trees and shrubs) and compacted soil (goat presences), and more easy to water evaporation post the rain. Wild Caatinga and Cactaceae field had lower values of ET because lower evaporation and because its plant species are more adapted to water loss control (stomatal regulation and water accumulation). Vico et al. (2015) observed that shifts in species composition may have significant implications for the long-term water balance of seasonally dry ecosystems, with higher abundance of drought-deciduous species resulting in larger fluctuations of soil moisture and an increase in deep percolation and hence groundwater recharge.

Table 1 - Comparison of data range of this work with literature.

\begin{tabular}{lccc}
\hline Variables & This work & Literature & References \\
\hline Aridity Index & $0.18-0.27$ & $0.1-0.5$ & Marengo and Bernasconi (2015) \\
Mean annual & $24-31$ & $22-32$ & Moura et al. (2007) \\
Temperature $\left({ }^{\circ} \mathrm{C}\right)$ & $180-650$ & $200-800$ & Moura et al. (2007); Nobrega et al. (2015) \\
Annual Rainfall $(\mathrm{mm})$ & $1450-3050$ & $1000-3000$ & Du et al. (2011); Yang et al. (2013) \\
Annual ET $(\mathrm{mm})$ & $0.7-2.6$ & $0.2-3.2$ & Du et al. (2011) \\
VPD $(\mathrm{kPa})$ & $-2.1--0.7$ & $-3.5-0$ & Dahlin, Fisher and Lawrence (2015) \\
$\Psi_{\text {soil }}(\mathrm{MPa})$ & & &
\end{tabular}

The main factor on VPD maintain constant values is regulated by plant transpiration, because evaporation tax is more significant post rainfall (Gondim et al., 2015). The data this work indicated that on cloudy periods the Caatinga species more transpired than on rainy periods. Thus, Wild Caatinga, Caatinga on management are Eucalyptus reforestation were the ecosystems with higher VPD values registered. Fabaceae crop and Cactaceae field had lower VPD values because one high evaporation values (one crop per year $=$ soil discovered) and other by lower plant transpiration (stomatal regulation and water accumulation), respectively. The annual mean of $\Psi_{\text {soil }}$ reflects the VPD, soil cover and depth roots presence (all are the similar groundwater depth)
(Scholz et al., 2010). Thus, Wild Caatinga and Caatinga on management were the ecosystems with higher $\Psi_{\text {soil }}$ values, and Cactaceae field and Fabaceae crop (depth of roots $<0.3 \mathrm{~m}$ ) with lower $\Psi_{\text {soil }}$ values. Eucalyptus reforestation has lower $\Psi_{\text {soil }}$ values because of its high transpiration tax. The VPD and Isoil were the variables more directly proportional with Aridity index to analyzed ecosystems, and confirmed by literature on areas with water stress (Santana and Encinas, 2016).

Climatic changes are likely to increase dry season duration and decrease soil moisture in tropical SDEs (Hulme and Viner, 1998; Wetherald and Manabe, 2002; Jung et al., 2010; Santana, 2016). The ecosystems were being drier over time mainly 
because of deficit on water balance (EMBRAPA SEMIÁRIDO, 2019). The studied ecosystems more efficient in relation of water balance (difference between precipitation and evapotranspiration) on descendent sequence of values were: Cactaceae field $(-1100 \mathrm{~mm})$, Wild Caatinga $(-1380 \mathrm{~mm})$, Caatinga on management (-1590 mm), Fabaceae crop (-2160 $\mathrm{mm})$, and Eucalyptus reforestation $(-2360 \mathrm{~mm})$. This showed two important results: i) the ecosystem more adaptaded to these environments were these with individuals of arid species (O. ficus indica), and this indicates the aridity trends on droughts periods; and ii) the importance to maintain the areas with legal protection environmental, to the desertification process does not accelerate. On mean of all ecosystems about AI, the region is below of Semiarid classification $\left(\mathrm{AI}_{\text {mean }}=0.198\right)$. Thus, the maps of climate classification would be revisited to attend (or to update) spot data on Brazilian Semiarid region.

\section{Conclusions}

1) The studied areas are hotter and drier over time.

2) The null hypothesis was refuted, between the ecosystems differences significant were found on variables ET, VPD and $\Psi_{\text {soil, }}$ variables directly influenced by land use.

3) The Fabaceae crop and Eucalyptus reforestation studied ecosystems already are on Arid classification according with studied aridity index. Wild Caatinga and Cactaceae field ecosystems are on Semiarid classification, but Caatinga on management ecosystem pass from Semiarid to Arid classification. In general, on mean of five ecosystems area classified on Arid climate.

4) The VPD and Isoil were the variables more directly proportional with Aridity index to analyzed ecosystems. These variables were determinants to water balance.

5) The Cactaceae field was the ecosystem more efficient to water use and stocked. This data show the better adaptability this plants species to environment than others ecosystems.

6) The perspective is to motivate the study of local climate changes (large scales) where occurs fast and perceptible changes on short period. Moreover, we would response the question: what the effect of large scales on small and global scales?

\section{References}

Arora, V.K., 2002. The use of the aridity index to assess climate change effect on annual runoff. Journal of Hydrology 265, 164-177. doi:10.1016/S0022-1694(02)00101-4
Dahlin, K.M., Fisher, R.A., Lawrence, P.J., 2015. Environmental drivers of drought deciduous phenology in the Community Land Model. Biogeosciences Discussion 12, 5803-5839. doi:10.5194/bgd-12-5803-2015

Du, S., Wang, Y.L., Kum, T., Zhang, J.G., Otsuki, K., Yamanak, N., Liu, G.B., 2011. Sapflow characteristics and climatic responses in three forest species in the semiarid Loess Plateau region of China. Agricultural and Forest Meteorology 151, 1-10. doi:10.1016/j.agrformet.2010.08.011

EMBRAPA SEMIÁRIDO. Empresa Brasileira de Pesquisa Agropecuária do Semiárido, 2019. Desertificação atinge grandes áreas do semiárido. Disponível: www.embrapa.br/semiarido. Acesso: 10 jan. 2019.

Hulme, M., Viner, D., 1998. A climate change scenario for the tropics. Climatic Change 39, 145176. doi:10.1023/a:1005376007729.

INSA. Instituto Nacional do Semiárido, 2019. Acervo digital. Disponível: http://insa.gov.br/. Acesso: 15 abr. 2019.

Gondim, P.S.D.S., Lima, J.R.D.S., Antonino, A.C., Hammecker, C., Silva, R.A., Gomes, C.A., 2015. Environmental control on water vapour and energy exchanges over grasslands in semiarid region of Brazil. Revista Brasileira de Engenharia Agrícola e Ambiental 19, 3-8. doi:10.1590/1807-1929/agriambi.v19n1p3-8

Jung, M., Reichstein, M., Ciais, P., Seneviratne, S.I., Sheffield, J., Goulden, M.L., Bonan, G., Cescatti, A., Chen, J., Jeu, R., Dolman, A.J., Eugster, W., Gerten, D., Gianelle, D., Gobron, N., Heinke, J., Kimball, J., Law, B.E., Montagnani, L., Mu, Q., Mueller, B., Oleson, K., Papale, D., Richardson, A.D., Roupsard, O., Running, S., Tomelleri, E., Viovy, N., Weber, U., Williams, C., Wood, E., Zaehle, S., Zhang, K., 2010. Recent decline in the global land evapotranspiration trend due to limited moisture supply. Nature 467, 951-954. doi:10.1038/nature09396.

Lima, C., Duarte, C.V.M.C., Melo, R.B., Souza, S.C., Lima, M.L.F., Costa, V.S.O., Cavalcante, K.V., Santana, O.A., 2019. Pré-diagnóstico da esquistossomose no semiárido: régua antropométrica e aplicativo colaborativo. Revista de Tecnologia e Sociedade 15, 272-293. doi: 10.3895/rts.v15n36.7809

Mainguet, M., 1994. Desertification: natural background and human mismanagement. 2. ed. Springer-Verlag, Heidelberg. doi:/10.1007/978-3-642-86184-0

Maliva, R.G., Missimer, T.M., 2012. Arid Lands Water Evaluation and Management. SpringerVerlag, Heidelberg. 
doi:10.1007/978-3-642-29104-3_2

Marengo, J.A., Bernasconi, M., 2015. Regional differences in aridity/drought conditions over Northeast Brazil: present state and future projections. Climatic Change 129, 103-115. doi:10.1007/s10584-014-1310-1

Moura, M.S.B., Galvincio, J.D., Brito, L.T.L., Souza, L.S.B., Sá, I.I.S., Silva, T.G. F., 2007. Clima e água de chuva no Semi-Árido, in: Brito, L.T.L., Moura, M.S.B., Gama, G.F.B. (eds.). Potencialidades da Água de Chuva no Semi-Árido Brasileiro. Embrapa Semi-Árido, Petrolina, pp. 37-59.

Nobrega, R.S., Farias, R.F.L., Santos, C.A.C., 2015. Temporal and spatial variability of rainfall in Pernambuco by extreme climatic indices. Revista Brasileira de Meteorologia 30, 171-180. doi:10.1590/0102-778620130624.

Rodal, M.J.N., Sampaio, E.V.S., Figueiredo, M.A., 1992. Manual sobre Métodos de Estudo Florístico e Fitossociológico: ecossistema caatinga. Sociedade Botânica do Brasil, Brasília, pp. 24.

Rubel, F., Kottek, M., 2010. Observed and projected climate shifts 1901-2100 depicted by world maps of the Köppen-Geiger climate classification. Meteorologische Zeitschrift 19, 135-141. doi:10.1127/0941-2948/2011/0258

Salazar, A., Baldi, G., Hirota, M., Syktus, J., Mcalpine, C., 2015. Land use and land cover change impacts on the regional climate of nonAmazonian South America: A review. Global and Planetary Change 128, 103-11. doi:10.1016/j.gloplacha.2015.02.009

Santana, O.A., 2016. Resistência social na Caatinga árida: a narrativa de quem ficou no colapso ambiental. Desenvolvimento e Meio Ambiente 38, 419-438. doi: 10.5380/dma.v38i0.43574

SANTANA, O.A., 2017. Minimum age for clearcutting native species with energetic potential in the Brazilian semi-arid region. Canadian Journal of Forest Research 47, 411-417. doi: 10.1139/cjfr2016-0392

Santana, O.A., Cuniat, G., Imaña-Encinas, J., 2010. Contribuição da vegetação rasteira na evapotranspiração total em diferentes ecossistemas do bioma cerrado, Distrito Federal. Ciência Florestal 20, 269-280. doi:10.5902/19805098

Santana, O.A., Encinas, J.I., 2016. Dendrophysiological plant strategies of Poincianella pyramidalis (Tul.) L.P. Queiroz after wood herbivory in semiarid region of Paraíba -
Brazil. Acta Scientiarum. Biological Sciences 38, 179-186. doi: 10.4025/actascibiolsci.v38i2.29089

Scholz, F.G., Bucci, S.J., Hoffmann, W.A., Meinzer, F.C., Goldstein, G., 2010. Hydraulic lift in a Neotropical savanna: experimental manipulation and model simulations. Agricultural and forest meteorology $\quad 150, \quad 629-639$. doi:10.1016/j.agrformet.2010.02.001

Schwartz, N.B., Uriarte, M., Gutiérrez-Vélez, V.H., Baethgen, W., Defries, R., Fernandes, K., PinedoVasquez, M.A., 2015. Climate, landowner residency, and land cover predict local scale fire activity in the Western Amazon. Global Environmental Change 31, 144-153. doi:10.1016/j.gloenvcha.2015.01.009

Thomas, C.D., Cameron, A., Green, R.E., Bakkenes, M., Beaumont, L.J., Collingham, Y.C., Erasmus, B.F.N., Siqueira, M.F., Grainger, A., Hannah, L., Hughes, L., Huntley, B., Van Jaarsveld, A., Midgley, G.F., Miles, L., Ortega-Huerta, M.A., Peterson, A.T., Phillips, O., Williams, S.E., 2004. Extinction risk from climate change. Nature 427, 145-148. doi:10.1038/nature02121

UNESCO. United Nations Educational, Scientific and Cultural Organization, 1979. Map of the World Distribution of Arid Regions: Map at scale 1:25,000,000 with explanatory note. UNESCO, Paris.

Vico, G., Thompson, S.E., Manzoni, S., Molini, A., Albertson, J.D., Almeida-Cortez, J.S., Fay, P.A., Feng, X., Guswa, A.J., Liu, H., Wilson, T.G., Porporato, A., 2015. Climatic, ecophysiological, and phenological controls on plant ecohydrological strategies in seasonally dry ecosystems. Ecohydroly 8, 660-681. doi:10.1002/eco. 1533

Wetherald, R.T., Manabe, S., 2002. Simulation of hydrologic changes associated with global warming. Journal of Geophysical Research: Atmospheres 107, 7-15. doi:10.1029/2001jd001195.

Yang, Y., Scott, R.L., Shang, S., 2013. Modeling evapotranspiration and its partitioning over a semiarid shrub ecosystem from satellite imagery: a multiple validation. Journal of Applied Remote Sensing 7, 1-16. doi:10.1117/1.JRS.7.073495

Zar, J.H., 2010. Biostatistical Analysis. 5th. ed. Prentice Hall, Upper Saddle River, pp. 944.

Zarch, M.A.A., Sivakumar, B., Sharma, A., 2015. Assessment of global aridity change. Journal of Hydrology 520, 300-313. doi:10.1016/j.jhydrol.2014.11.033 